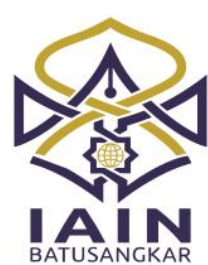

JURNAL TA'DIB, Vol 21 (2), 2018, (Juli-Desember)

ISSN : 1410-8208 (Print) 2580-2771 (Online)

Tersedia online di http://ecampus.iainbatusangkar.ac.id/ojs/index.php/takdib/index

\title{
PENINGKATAN KETERAMPILAN BERBAHASA SISWA MELALUI PEMANFAATAN MEDIA TEKA-TEKI SILANG: MENCIPTAKAN KELAS YANG MENYENANGKAN
}

\section{Syofiani*)}

Universitas Bung Hatta

Email: syofiani.jufri@gmail.com

\section{Zaim}

Universitas Negeri Padang

Email: $\underline{\text { mzaim_unp@yahoo.com }}$

\section{Syahrul R.}

Universitas Negeri Padang

Email:syahrulramadhan@gmail.com

\section{Agustina}

Universitas Negeri Padang

Email: $\underline{\text { tien_agustina@yahoo.com }}$

\begin{abstract}
Abstrak: This article contains a study about the use of crossword media in improving the language skills of elementary school students as an effort to create a fun class. The problem was students' lack of eagerness to emotionally involve in learning process. This condition caused an impact on students' unsatisfaying learning outcomes that is 80 . To overcome this problem, crossword puzzle media are used in learning by referring to the research models of Kemmis and Taggart. The data were collected by using observation sheets, interview guidelines, questionnaires, tests of student learning outcomes and field observations. At the end of the study, it was found that both the students' learning outcomes and activities, and the teacher performance in planning and implementing teaching increased from cycle I to cycle II. As the result, the learning exceeded the target of the minimum standard of completeness. Thus, the utilization of crossword puzzles is considered to able to improve students' language skills, as well as create fun classes.
\end{abstract}

Kata Kunci: Cross Word Puzzle, Language skills, Fun classes

\section{PENDAHULUAN}

$\mathrm{P}$ embelajaran bahasa Indonesia merupakan dasar penghela bagi mata pelajaran lainnya. Hal ini merupakan tanggung jawab besar bagi guru sebagai ujung tombak proses pembelajaran. Sehubungan dengan hal tersebut, keterampilan berbahasa di sekolah dasar men-jadi bahan kajian penting untuk dipertimbangkan dalam pengua-saan dasar kemampuan berbahasa siswa, karena siswa sekolah dasar adalah dasar untuk menanamkan konsep termasuk konsep berbahasa. Sejalan dengan perkembangan ilmu pengetahuan dan teknologi dewasa ini, siswa dituntut untuk mempunyai kemampuan berbahasa yang baik. Seseorang yang mempunyai kemampuan berba-hasa yang memadai akan lebih mudah menyerap dan menyampaikan informasi baik secara lisan maupun tulisan. Keterampilan berbahasa itu sendiri terdiri dari empat aspek, yaitu menyimak atau mendengarkan, berbicara, membaca, dan menulis. Siswa harus menguasai keempat aspek tersebut secara terintegrasi agar mereka terampil berbahasa. Oleh sebab itu, pembelajaran keterampilan berbahasa di sekolah tidak hanya menekankan pada aspek teori saja, tetapi bagaimana agar siswa mampu menggunakan bahasa se-bagaimana fungsinya, yaitu sebagai alat untuk berkomunikasi. Menurut pandangan whole language berbicara tidak diajarkan sebagai 
suatu pokok bahasan yang berdiri sendiri, melainkan meru-pakan satu kesatuan dalam pem-belajaran bahasa bersama dengan keterampilan berbahasa yang lain. Kenyataan tersebut dapat dilihat bahwa dalam proses pembelajaran bahasa, keterampilan berbahasa tertentu dapat dikaitkan dengan keterampilan berbahasa yang lain. Pengaitan keterampilan berbahasa yang dimaksud tidak selalu melibatkan keempat keterampilan berbahasa sekaligus, melainkan dapat hanya menggabungkan dua keterampilan berbahasa saja sepanjang aktivitas berbahasa yang dilakukan bermakna. Namun dalam kenyataannya, pelaksanaan pembelajaran bahasa Indonesia di Sekolah Dasar Islam Khaira Ummah tepatnya pada siswa kelas I masih terkesan bahwa guru terlalu banyak me-nyuapi materi tentang bahasa, ku-rang pada aspek mengajarkan penggunaan bahasa dalam konteks sehari-hari.

Hal ini dapat diamati dalam pembelajaran, siswa kurang terli-hat aktif dalam belajar, tidak bersemangat, tidak menikmati pembelajaran. Dengan arti kata, kelas sebagai tempat belajar tidak mam-pu menjadi kelas yang menye-nangkan bagi siswa, siswa merasa bosan dengan pembelajaran yang disajikan guru. Hal ini selaras dengan apa yang ditegaskan oleh Laksmi, dkk. (2014) bahwa "kecenderungan pembelajaran saat ini masih berpusat pada guru de-ngan bercerita atau berceramah". Pemilihan metode, strategi, dan media pembelajaran dipandang dapat mewujudkan pembelajaran yang lebih menarik, interaktif, dan bermakna. Singkatnya, kegiatan pembelajaran menuntut dikurangi-nya metode ceramah dan diganti dengan pemakaian banyak media. Apalagi di era digital sekarang ini siswa tidak lagi disuguhi hal-hal yang bersifat menceramahi mereka tetapi lebih pada kegiatan pembelajaran yang menekankan pada keterampilan proses dan active learning, maka kiranya peranan media pembelajaran, menjadi semakin penting.

Siswa sekolah dasar adalah awal dari sebuah proses pembe-lajaran, atau dapat juga dikatakan sebagai pondasi atau basis untuk perkembangan berbahasa anak, jika bagus dasar pemerolehan bahasa mereka akan bagus juga pemerolehan bahasa mereka sampai ke tingkat yang lebih tinggi nantinya. Oleh sebab itu, perlu diperhatikan secara cermat bagaimana cara mengajar siswa terutama pada kelas rendah. Di samping itu, siswa sekolah dasar juga memiliki karakter yang be-ragam sehingga ketika berbicara juga dipengaruhi oleh karakter mereka masing-masing. Karakteristik berasal dari kata karakter yang berarti tabiat watak, pemba-waan, atau kebiasaan yang dimili-ki oleh individu yang relatif tetap. Karakteristik adalah mengacu kepada karakter dan gaya hidup seseorang serta nilai-nilai yang berkembang secara teratur sehingga tingkah laku menjadi lebih konsisten dan mudah diperhatikan. Setiap siswa adalah individu yang menerima pengaruh dari seseorang atau sekelompok orang dan itu ter-jadi dalam proses pembelajaran.

Proses pembelajaran pada satuan pendidikan diselenggarakan secara interaktif, inspiratif, menyenang-kan, menantang, memotivasi peserta didik untuk berpartisipasi aktif serta mem-berikan ruang yang cukup bagi prakarsa, kreati-vitas dan kemandirian sesuai dengan bakat, minat dan perkembangan fisik serta psikologis siswa. Setiap tahapan perkem-bangan siswa memiliki ciri khusus dengan perkembangan lain sehingga untuk dapat memberikan stimulasi dan mengarahkan pembentukan perilaku siswa perlu pula diketahui ciri khusus dari setiap tahapan perkembangan tersebut. Guru harus mampu memahami karakter siswa terutama terkait dengan keterampilan berbahasa mereka. Agar proses 
pembelajaran berjalan lancar dan baik, guru dapat menggunakan berbagai cara misalnya merancang media yang menarik sehingga pembelajaran menjadi lebih menyenangkan.

Hal ini selaras dengan apa yang dikatakan Aqib, 2014: 50, bahwa media adalah "segala sesuatu yang dapat digunakan untuk menyalurkan pesan dan merangsang terjadinya proses belajar pada siswa". Sebab dengan menggunakan media proses pembelajaran jadi lebih menarik dan peserta didik lebih mema-hami apa yang disampaikan oleh guru. Salah satu media yang dipandang dapat meningkatkan keterampilan berbahasa siswa adalah media teka-teki silang. Banyak penelitian yang sudah dilakukan terkait dengan penggunaan media teka teki silang dalam pembelajaran, di antaranya Orawiwatnakul, Wiwat, 2013; Pavlova, Iglika V.; Lewis, Kayla C., 2013; Joag, Sushama D, 2014; Kamboj, Pooja; Singh, Sushil Kumar, 2015; Rantika dan Abdullah, 2015, Merkel, Warren, 2016; dan Priantini, et all, 2016

\section{Media Teka-teki Silang}

Banyak penelitian yang terkait dengan penggunaan media teka-teki silang sebagai salah satu media dalam pembelajaran (Saxena, et all 2009; Njoroge, 2013; Davis, 2014; Tarigas, 2014; Retno et all 2014; Warren, 2016; Ermaita, 2016; Rahmah, 2016;) yang dipandang ampuh dan efektif dalam menciptakan suasana belajar yang menyenangkan, apakah itu pada siswa level rendah ataupun pada level mahasiswa. Hal ini juga selaras dengan apa yang dinyatakan oleh Khalilullah (2013: 127) bahwa "tekateki silang merupakan "salah satu media pembelajaran yang dapat digunakan dalam pembelajaran untuk melatih keterampilan berpikir dan penguasaan kosa-kata". Media ini sangat mudah untuk dibuat oleh guru dan dapat digunakan untuk semua tingkatan, baik untuk pemula, menengah atau yang sudah lanjut. Di samping itu, materi yang dapat dipilih dapat disesuaikan dengan tujuan pembelajaran. Sedangkan yang dimaksud dengan teka-teki bergambar adalah permainan untuk menduga, menebak dan menerka soal berupa kalimat, cerita atau gambar ditemukan secara samar-samar, biasanya untuk mengasah pikiran sesorang yang dihiasi dengan gambar baik gambar barang, orang, binatang, tumbuhan dan sebagainya. Lebih lanjut, Haryono mengatakan bahwa tujuan teka-teki silang dalam pembelajaran ini adalah untuk mengasah otak siswa dalam berpikir dan menambah perbendaharaan kosakata pada suatu mata pel-ajaran. Dengan menggunakan teka-teki silang, maka siswa akan bersemangat untuk belajar dan juga menambah perbendaharaan ter-hadap kosakata mereka, karena dalam teka-teki silang terdapat unsur permainan yang dapat me-nimbulkan kegairahan dan rasa senang dalam belajar tanpa harus berhadapan dengan situasi yang menjemukan. (Abdullah, 2015: 128). Lebih lanjut dikatakan Ariwibowo (2014: 3) bahwa "teka-teki silang atau disingkat TTS adalah suatu permainan di mana kita harus mengisi ruang-ruang kosong (berbentuk kotak putih) dengan huruf-huruf yang membentuk sebuah kata berdasarkan petunjuk yang diberikan". Petunjuknya biasa dibagi ke dalam kategori 'mendatar' dan 'menurun' tergantung arah kata-kata yang harus diisi". Berdasarkan pendapat tersebut dapat disimpulkan bahwa teka teki silang (Crossword Puzzle) adalah suatu permainan di mana kita harus mengisi ruang-ruang kosong (berbentuk kotak putih) dengan huruf-huruf yang membentuk sebuah kata berdasar-kan petunjuk yang diberikan.

Banyak manfaat yang dapat diperoleh melalui teka-teki silang dia antaranya meningkatkan akti-vitas dan hasil belajar siswa sebab dalam mengisi teka-teki silang 
dilakukan dengan pikiran yang jernih, rileks dan tenang sehingga membuat memori siswa bekerja dengan baik, dan daya ingat pun meningkat. Selain itu, permainan teka-teki silang ini membuat siswa berpikir, mencari, dan menemukan jawaban tetapi tetap dalam kondisi bermain yang menyenangkan. Jadi, media teka-teki silang adalah suatu media yang sangat tepat un-tuk mengajarkan materi yang konsepnya untuk mengajarkan keterampilan menulis, menghafal ko-sakata dan media yang menye-nangkan karena sifatnya berupa media permainan. Menurut Khalillah (2013:17) "Teka-teki silang merupakan salah satu media pembelajaran yang dapat digunakan untuk pembelajaran keterampilan menulis". Media ini sangat mudah untuk dibuat oleh guru dan dapat diguna-kan untuk semua tingkatan, baik untuk pemula, menengah atau yang sudah lanjut, di samping itu juga materi yang dapat dipilih sesuai dengan tujuan pembelajarannya.

Dengan adanya media pembelajaran, tentunya dapat memotivasi kita para guru un-tuk memperkaya teknik pembel-ajaran kita agar lebih variatif. De-ngan demikian, siswa akan lebih tertarik, aktif, senang, dan pem-belajaran pun akan lebih bermakna.

Sebagai sebuah media pem-belajaran, media teka-teki silang efektif dilakukan dalam upaya me-ningkatkan keterampilan berbahasa siswa kelas I SDI Khaira Ummah Padang. Efektivitas peng-gunaan media ini telah dibuktikan oleh Ayu, dkk. (2013) dan Fathonah, dkk. (2013) pada pel-ajaran Kimia, Elviza (2013) pada pelajaran Bahasa Indonesia, dan Laksmi, dkk. (2014) pada pel-ajaran IPS. Dari beberapa hasil penelitian tersebut diperoleh bah-wa media teka-teki silang ini di-yakini sebagai sebuah media yang ampuh dalam meningkatkan aktivitas belajar siswa. Pembela-jaran menjadi sesuatu yang meng-gembirakan dan menarik, sehingga tentu saja diharapkan hasil belajar siswa akan meningkat.

Berdasarkan permasalahan tersebut, maka dirumuskan masa-lah penelitian ini yaitu apakah penggunaan media teka-teki silang dapat meningkatkan keterampilan berbahasa siswa dalam upaya menciptakan kelas yang menyenangkan?

\section{Pembelajaran yang Menyenangkan}

Pembelajaran yang menyenangkan adalah suasana pembelajaran yang dapat memusatkan perhatian siswa secara penuh saat belajar sehingga curah waktu perhatiannya (time on task) tinggi. Lebih lanjut, dapat juga dikatakan bahwa pembelajaran menyenangkan dapat diartikan seba-gai pembelajaran yang dapat me-narik perhatian siswa dengan berbagai metode yang diterapkan, sehingga saat pembelajaran berlangsung siswa tidak merasa bosan. Dengan demikian, dapat disimpulkan bahwa pembelajaran menyenangkan adalah suatu proses pembelajaran yang berlang-sung dalam suasana yang menyenangkan dan mengesankan. Suasana pembelajaran yang me-nyenangkan dan berkesan akan menarik minat siswa untuk terlibat secara aktif, sehingga tujuan pembelajaran dapat dicapai maksimal. Dengan bermain anak-anak akan berusaha untuk memi-liki keinginan dan mencapai keinginannya. Melalui bermain, semua aspek perkembangan anak dapat ditingkatkan. Dengan ber-main secara bebas anak dapat berekspresi dan bereksplorasi untuk memperkuat hal-hal yang sudah diketahui dan menemukan hal-hal baru. Apalagi dengan diberlakukannya full day di sekolah tersebut akan membuat siswa jenuh.

Pembelajaran yang menye-nangkan dapat memberikan tan-tangan kepada anak untuk berpi-kir, mencoba belajar lebih lanjut, penuh dengan percaya diri dan mandiri untuk mengembangkan potensi diri optimal. Dengan de-mikian, diharapkan 
kelak anak menjadi manusia yang berkarakter penuh percaya diri, menjadi dirinya sendiri. Beberapa cara yang dapat dipakai guru untuk mencip-takan pembelajaran melalui yang menyenangkan antara lain dengan menggunakan metode yang ber-variasi, menciptakan suasana yang rileks, memotivasi peserta didik, dan menyapa peserta dengan ha-ngat dan antusias. Dalam konteks pembelajaran menyenangkan guru dituntut tidak hanya memerankan diri sebagai pengajar atau pendi-dik, tetapi juga sebagai fasilitator dan motivator bagi peserta didik.

Sebuah pembelajaran yang menyenangkan biasanya memili-ki ciri seperti: (a) menciptakan Lingkungan tanpa stress (rileks), (b) Materi yang diberikan rele-van tingkat perkembangan anak, (c) Belajar secara emosional, se-perti adanya humor dan dukung-an semangat, (d) Melibatkan se-mua indera dan otak kiri (anali-tis) maupun kanan (sosial), dan (e) Menantang peserta didik dan mengekspresikan apa yang se-dang dipelajari. Di samping itu, sebuah pembelajaran yang me-nyenangkan juga memiliki ka-rakteristik seperti: (a) rileks, (b) bebas dari tekanan, (c) aman, (d) menarik, (e) bangkitnya minat belajar, (f) adanya keterlibatan penuh, (g) perhatian siswa tercu-rah, (h) lingkungan belajar yang menarik (misalnya, keadaan ke-las terang, pengaturan tempat du-duk leluasa untuk peserta didik bergerak), (i) bersemangat, (j) perasaan gembira, dan (k) kon-sentrasi tinggi. Jika diamati ling-kungan belajar di Sekolah Dasar Islam Khaira Ummah dapat dika-takan sudah memenuhi kriteria kelas menyenangkan walaupun masih belum semua persyaratan dipenuhi. Oleh sebab itu, dibutuhkan kreativitas guru dalam merancang sebuah pembelajaran sehingga betul-betul aktivitas berbasis siswa dan tujuan pem-belajaran dapat tercapai. Sehubungan dengan hal tersebut, pembelajaran yang menarik dan menyenangkan merupakan suatu bagian penting dalm mendorong perkembangan bahasa siswa, karena dapat mendorong anak un-tuk mengungkapkan diri di depan orang, salah satu melalui perma-inan bahasa dalam bentuk teka-teki silang.

Sekolah Dasar Islam Khaira Ummah (SDI Khaira Ummah) Kota Padang adalah satu dari banyak sekolah dasar yang berbasis Islam dengan peringkat akreditasi A. Karena sekolah ini berbasis Islam, sehingga banyak mata pelajaran tambahan yang diberikan kepada siswa seperti Akidah, Alquran, Fiqih, Sejarah Islam, Bahasa Arab, dan Tahfiz, di samping mata pelajaran wajib lainnya. Namun, untuk kelas rendah yaitu I sampai dengan kelas III belum diajarkan materi yang terkait dengan agama Islam seperti yang sudah disebutkan sebelumnya. Materi tersebut baru diajarkan kepada siswa mulai kelas tinggi mulai dari kelas IV sampai dengan kelas VI. Kurikulum yang digunakan di sekolah ini adalah kurikulum 2013, berarti sesuai dengan sub-stansi kurikulum 2013, aktivitas harus lebih banyak dilakukan siswa daripada guru, sehingga memungkinkan siswa yang lebih aktif di dalam kelas. Berdasarkan observasi yang dilakukan di kelas I, tidak begitu tampak aktivi-tas siswa di dalam kelas. Aktivi-tas lebih didominasi oleh guru, misalnya menggunakan metode berceramah, sehingga siswa lebih banyak diam mendengar apa yang disampaikan guru. Tentu saja ini tidak sejalan dengan marwahnya Kurikulum 2013 ter-sebut. Salah satu yang menye-babkan hal ini adalah guru belum menggunakan media yang variatif dalam pembelajaran. Ketika hal ini dikonfirmasikan kepada wali kelas II ibu Siti Rahmaita, S.Pd.i dikatakan bahwa dari 25 orang siswa kelas I hanya 5 orang yang aktif 
di dalam kelas. Dengan demikian, ada 20 orang siswa yang belum terlibat secara aktif dalam proses pembelajaran. Tentu saja hal ini akan berdam-pak terhadap hasil belajar siswa apalagi mereka akan naik ke kelas II. Berdasarkan hal terse-but, dirasa perlu untuk mencari-kan solusi yang tepat salah satu melalui penggunaan media teka-teki silang. Untuk mengoptimalkan ha-sil belajar siswa, terutama pada aspek keterampilan berbicara, diperlukan metode pengajaran yang lebih menekankan pada aktivitas belajar aktif dan kreativitas, sehingga seperti yang dikatakan oleh Setyawati (2012:4), "seorang guru dalam menggunakan media memiliki arti penting dalam proses pem-belajaran dengan tujuan agar siswa dalam mengikuti pembelajaran tidak bosan dan aktivitas pembelajaran lebih menyenang-kan". Untuk itu, tentu diperlukan kreativitas guru dalam menggunakan media pembelajaran yang tepat tetapi fleksibel untuk dite-rapkan di dalam kelas.

\section{METODE PENELITIAN}

Penelitian ini menggunakan desain model Kemmis dan Mc Taggart yang terdiri atas beberapa tahapan.Tahap perenca-naan, merupakan langkah awal dalam penelitian. Dalam tahapan ini dilakukan beberapa persiapan sebelum dilaksanakannya penelitian. Tahap pelaksanaan, tahap dilakukannya penelitian terhadap media teka-teki silang yang telah sebe-lumnya direncanakan dan dituang-kan ke dalam RPP. Adapun tahapn penelitiannya adalah:

1. Tahap pengamatan, pengamat-an dilaksanakan selama proses penelitian berlangsung. Hal ini dilakukan oleh observer sebagai mitra melakukan penelitian.

2. Tahap refleksi, berupa evaluasi terhadap tindakan yang telah dilaku-kan dalam tahap pelaksanaan (tindakan) untuk mengetahui tingkat keberhasilan yang telah dicapai.

\section{Peserta}

Subjek penelitian adalah siswa kelas I Sekolah Dasar Islam Khaira Ummah Kota Padang tahun ajaran 2018/2019 yang berjumlah 25 orang yang terdiri 11 laki-laki dan 14 perempuan dan guru yang mengajar di kelas I.

\section{Instrumen}

Instrumen dalam penelitian lembaran observasi, berupa lembar kinerja guru dan lembar aktivitas siswa yang digunakan pada saat pembelajaran berlangsung. Lembar wawancara, berisi pertanyaan-pertanyaan mengenai penggunaan media teka-teka silang. Pertanyaan diajukan kepada wali kelas terha-dap implementasi media tekateki silang.

\section{Lembar pertanyaan}

berupa angket, berisi pertanyaan sederhana mengenai pembelajaran yang telah dilakukan oleh guru dengan meng-gunakan media teka-teki silang.

\section{Soal tes hasil belajar}

berupa soal tes menceritakan kembali sebuah gambar dengan menggunakan bahasa siswa sendiri.

\section{Catatan lapangan}

berisi hal-hal penting yang dicatat selama pem-belajaran menggunakan teka-teki silang berlangsung

\section{Teknik Pengolahan Data dan Analisis Data}

Pengolahan data dalam penelitian diperoleh melalui lembar observasi aktivitas siswa dan lembar observasi kinerja guru dalam proses merencanakan dan pro-ses pembelajaran. Pengolahan aktivitas siswa dilakukan sesuai dengan skor yang diperoleh. Kare-na kurikulum yang digunakan dalam proses pembelajaran ini adalah Kurikulum 2013, maka penggambaran aspek softskills harus 
secara jelas digambarkan dalam RPP yang dirancang oleh guru. Aspek yang dinilai yaitu kerja sama, keaktifan, dan tang-gung jawab. Setiap aspek terdiri dari 3 indikator sehingga skor ideal adalah 9. Jumlah skor yang diperoleh siswa kemudian digolongkan ke dalam 5 interpretasi, yaitu Baik Sekali (BS) jika persentase 81\%-100\%, Baik (B) jika persentase $61 \%-80 \%$, Cukup (C) jika persentase $41 \%-60 \%$, Kurang (K) jika persantase $21 \%$ - 40\%, dan Kurang Sekali (KS) jika persentase $0 \%-20 \%$. Kinerja guru diolah berdasarkan skor me-lalui lembar observasi kinerja gu-ru. Setiap aspek yang dinilai diberi rentang skor 0 - 3. Kinerja guru mulai dari perencanaan sampai proses pembelajaran juga meng-gunakan interpretasi seperti hal-nya penilaian siswa yaitu 5 interpretasi.

Pengolahan data digunakan angka dan penskoran berdasarkan kunci jawaban dengan rentangan nilai $0-4$ jumlah skor maksimal yaitu 20, sehingga skor yang diperoleh dibagi 20 kemudian dikalikan dengan 100. Nilai akhir yang diperoleh dikategorikan menjadi tuntas atau belum tuntas. Siswa dikategorikan tuntas jika nilai mencapai KKM, yaitu 75 dan belum tuntas jika nilainya kurang dari KKM yaitu 75 .

Analisis data dilakukan agar data-data yang diperoleh saling terkait dan mendukung. Analisis data dalam penelitian ini dimulai dari menelaah semua data yang diperoleh dari observasi, wawan-cara, catatan lapangan, dan hasil keterampilan berbahasa siswa.

\section{HASIL DAN PEMBAHASAN}

Penggunakan media teka-teki si-lang dalam meningkatkan keterampilan berbahasa siswa kelas I SDI Khaira Ummah terdiri dari 3 tahapan. Ketiga tahapan tersebut adalah: (1) tahap perencanaan, (2) tahap pelaksanaan, dan (3) tahap hasil. Pada tahap perencanaan, RPP yang dirancang oleh guru disesuaikan dengan menambahkan media teka-teki silang, sehingga nampak ada perubahan pada aktivitas pembelajaran. Penerapan media teki-teki silang ini agar siswa tidak jenuh dalam belajar karena media tekateki silang ini mengajak siswa untuk berpikir sambil belajar. Di sam-ping itu, melalui media teka-teki silang ini siswa akan lebih mudah dalam menkonkretkan apa yang mereka lihat dan amati secara langsung.

Peningkatan penilaian kiner-ja guru dalam perencanaan dapat dilihat dalam tabel 1 berikut ini:

Tabel 1: Kinerja Guru Merancang Perencanaan

\begin{tabular}{|c|c|c|c|c|c|c|}
\hline \multirow[b]{2}{*}{$\begin{array}{c}\text { Kegia } \\
\tan \end{array}$} & \multirow[b]{2}{*}{$\begin{array}{c}\text { Pers } \\
\text { enta } \\
\text { se }\end{array}$} & \multicolumn{5}{|c|}{ Interpretasi } \\
\hline & & $\begin{array}{c}\text { Bai } \\
\mathrm{k} \\
\text { Sek } \\
\text { ali }\end{array}$ & Baik & $\begin{array}{l}\mathrm{Cu} \\
\text { kup }\end{array}$ & $\begin{array}{c}\mathrm{Ku} \\
\mathrm{rang}\end{array}$ & $\begin{array}{c}\mathrm{Ku} \\
\text { rang } \\
\text { Sekali }\end{array}$ \\
\hline $\begin{array}{c}\text { Sik } \\
\text { lus I }\end{array}$ & 85,2 & $\sqrt{ }$ & - & - & - & - \\
\hline $\begin{array}{c}\text { Sik } \\
\text { lus II }\end{array}$ & $\begin{array}{c}88,3 \\
5\end{array}$ & $\sqrt{ }$ & - & - & - & - \\
\hline $\begin{array}{c}\text { Sik } \\
\text { lus III }\end{array}$ & $\begin{array}{c}98,5 \\
6\end{array}$ & $\sqrt{ }$ & - & - & - & - \\
\hline
\end{tabular}

\section{Kinerja Guru}

Pada siklus I, guru membagi siswa atas lima kelompok dengan menerapkan penggunaan media teka-teki silang pada masing-masing kelompok, namun penerapan media ini belum membuat situasi kelas tidak menarik malah masih terkesan kurang kondusif. Selanjutnya, dilanjutkan siklus II media teka-teki silang diberikan kepada semua kelompok. Ternya-ta strategi yang dilakukan guru cukup membuat kelas menjadi heboh dan siswa antusias untuk mengikutinya. Hal ini disebabkan karena siswa dapat secara bebas mengisi pertanyaan yang terdapat dalam teka-teki silang tersebut.

Sebelum diskusi kelompok dilaksanakan, guru menyampaikan beberapa aturan main bagaimana cara mengisi teka-teki silang dan 
apa sanksi yang diberikan jika kelompok berbuat kesalahan. Namun, guru memberika hadiah jika ada di antara kelompok yang dapat mengisi teka-teki silang dalam waktu yang sudah disepakati.

Pada akhir pembelajaran dalam siklus II masih ada siswa yang tidak mau terlibat dalam aktivitas pembelajaran, sehingga pada siklus III guru membuat aturan baru. Jika ada di antara anggota kelompok yang tidak ikut berpartisipasi maka akan dikenai pengurangan skor. Tujuannya agar tidak ada siswa yang tidak ikut berpartisipasi da-lam kegiatan pembelajaran semua-nya bertanggung jawab dalam tugas kelompok.

Keberhasilan sebuah kelompok adalah kerja sama tim sehingga tidak ada satu pun siswa yang tidak ikut dalam kelompok. Hasilnya cukup memuaskan, ternyata setelah disampaikan hal tersebut hampir semua siswa aktif dalam kegiatan dalam mengi-si teka-teki silang yang diberikan oleh guru. Peningkatan aktivitas guru dalam melaksanakan pembelajaran dapat dilihat lewat tabel 2 berikut ini:

Tabel 2 Peningkatan Kinerja Guru dalam Melaksanakan Pembelajaran

\begin{tabular}{|c|c|c|c|c|c|c|}
\hline \multirow{2}{*}{$\begin{array}{c}\text { Kegia } \\
\text { tan }\end{array}$} & \multirow{2}{*}{$\begin{array}{c}\text { Per } \\
\text { Senta } \\
\text { Se }\end{array}$} & $\begin{array}{c}\text { Bai } \\
\text { k }\end{array}$ & $\begin{array}{c}\text { B } \\
\text { Sek } \\
\text { ali }\end{array}$ & $\begin{array}{c}\text { Cu } \\
\text { k }\end{array}$ & $\begin{array}{c}\text { Ku } \\
\text { rang }\end{array}$ & $\begin{array}{c}\text { Ku } \\
\text { rang } \\
\text { Sek } \\
\text { ali }\end{array}$ \\
\hline $\begin{array}{c}\text { Siklus } \\
\text { I }\end{array}$ & 82 & $\sqrt{ }$ & - & - & - & - \\
\hline $\begin{array}{c}\text { Siklus } \\
\text { II }\end{array}$ & 85,33 & $\sqrt{n y y y y}$ \\
\hline $\begin{array}{c}\text { Siklus } \\
\text { III }\end{array}$ & 95,42 & $\sqrt{ }$ & - & - & - & - \\
\hline
\end{tabular}

\section{Aktivitas Siswa}

Pada tahapan pertama, guru membagi siswa atas lima kelompok. Masing-masing kelompok beranggotakan lima orang. Kemudian, masing-masing kelompok diberi satu teka-teki silang dengan tema sesuai dengan tema pelajaran yaitu lingkungan keluarga.
Setelah itu, siswa disuruh mengisi teka-teki silang yang sudah disiapkan oleh guru. Pada tahap ini, masih banyak siswa yang tidak ikut dalam proses pembelajaran, atau masih banyak yang diam sambil memperhahatikan teman-temannya yang lain. Dalam berkelompok, hanya 2-3 orang siswa yang terlibat aktif. Bahkan yang lebih banyak adalah mengganggu kegiatan kelompok lain. Hal ini membuat pembelajaran menjadi heboh dan tidak kondusif.

Namun, dari hasil penga-matan, siswa terlihat senang keti-ka guru menggunakan media teka-teki silang ini. Mereka antusias dan bersorak ketika ada kelompok mereka dapat menjawab pertanyaan dalam teka-teki silang tersebut. Apalagi ketika kelompok dapat menyelesaikan isian teka-teki silang tersebut, guru memberikan acungan jempol dan bertepuk tangan secara bersama-sama sehingga mendorong kelompok yang lain untuk menyelesaikan isian teka-teki silang tersebut. Hal ini menandakan bahwa ada keinginan siswa untuk berpikir lebih baik dalam suasana pembelajaran yang menyenangkan.

Masing-masing peningkatan penilaian aktivitas pembelajaran dapat dilihat dalam tabel 3 berikut ini.

Tabel 3 Perbandingan Nilai Aktivitas Siswa

\begin{tabular}{|c|c|c|c|c|c|}
\hline \multirow{2}{*}{$\begin{array}{c}\text { Kegia } \\
\text { tan }\end{array}$} & $\begin{array}{c}\text { Baik } \\
\text { Sekali }\end{array}$ & $\begin{array}{c}\text { Bai } \\
\mathrm{k}\end{array}$ & $\begin{array}{c}\mathrm{Cu} \\
\mathrm{kup}\end{array}$ & $\begin{array}{c}\mathrm{Ku} \\
\text { rang }\end{array}$ & $\begin{array}{c}\mathrm{Ku} \\
\text { rang } \\
\text { Sekali }\end{array}$ \\
\hline $\begin{array}{c}\text { Siklus } \\
\text { I }\end{array}$ & 16 & 32 & 32 & 20 & - \\
\hline $\begin{array}{c}\text { Siklus } \\
\text { II }\end{array}$ & 44 & 32 & 24 & - & - \\
\hline $\begin{array}{c}\text { Siklus } \\
\text { III }\end{array}$ & 88 & 12 & - & - & - \\
\hline
\end{tabular}

\section{Hasil Belajar Siswa}

Keterampilan berbahasa siswa kelas I SDI Khaira Ummah dengan menggunakan teka teki silang mengalami peningkatan mulai dari siklus I, II, dan III. Ini dapat dilihat melalui penguasaan berbahasa siswa 
seperti dalam tabel 3. Di samping itu, melalui media teka-teki silang ini juga memberikan pengalaman belajar secara langsung kepada siswa, melatih keterampilan berpikir siswa, dan melatih kerja sama antar siswa dalam kelompok.

Adapun peningkatan hasil belajar siswa selama penelitian yang dimulai dari siklus I, siklus II, dan siklus III dapat dilihat dalam tabel 4 berikut ini.

Tabel 4 Perbandingan Tes Keterampilan

Berbahasa dan Persentase Siswa

\begin{tabular}{|l|l|c|c|c|c|}
\hline \multirow{2}{*}{ No. } & \multirow{2}{*}{$\begin{array}{c}\text { Kegia } \\
\text { tan }\end{array}$} & $\begin{array}{c}\text { Tunta } \\
\text { s }\end{array}$ & $\begin{array}{c}\text { Be } \\
\text { lum } \\
\text { Tunta } \\
\text { s }\end{array}$ & $\begin{array}{c}\text { Tun } \\
\text { tas }\end{array}$ & $\begin{array}{c}\text { Be } \\
\text { lum } \\
\text { Tun } \\
\text { tas }\end{array}$ \\
\hline 1 & $\begin{array}{l}\text { Data } \\
\text { Awal }\end{array}$ & 6 & 19 & 24 & 76 \\
\hline 2 & $\begin{array}{l}\text { Siklus } \\
\text { I }\end{array}$ & 11 & 14 & 44 & 56 \\
\hline 3 & $\begin{array}{l}\text { Siklus } \\
\text { II }\end{array}$ & 18 & 7 & 72 & 28 \\
\hline 4 & $\begin{array}{l}\text { Siklus } \\
\text { III }\end{array}$ & 22 & 3 & 88 & 12 \\
\hline
\end{tabular}

Berdasarkan hasil dari penilaian pada aspek kinerja guru, ak-tivitas siswa, dan hasil kete-rampilan berbahasa siswa dapat dilihat terjadi peningkatan dari siklus I, II, dan III. Hal ini dapat dilihat dari data awal yang diperoleh melalui guru kelas. Kemudian dicobabandingkan dengan data pada setiap siklus. Artinya, media teks-teki silang dipandang dapat meningkatkan keterampilan berbahasa siswa dan siswa merasa senang dan bersemangat untuk mengikuti pembelajaran. Hal ini juga seperti yang sudah ditemukan melalui penelitian terdahulu bahwa melalui penggunaan media teka-teki silang mampu membuat suasana pembelajaran menjadi menarik.

\section{KESIMPULAN DAN REKOMENDASI}

Berdasarkan analisis data awal sampai hasil per siklus dapat disimpulkan bahwa media teka-teki silang mampu meningkatkan keterampilan berbahasa siswa ke-las I SDI
Khaira Ummah. Hal ini dapat dilihat terjadi peningkatan pada setiap siklus. Di samping itu, aktivitas belajar siswa juga sema-kin baik, siswa antusias dalam belajar, bersemangat, dan semua ikut berpartisipasi dalam kegiatan pembelajaran. Tidak ada siswa yang bermalasan karena semuanya berpikir untuk mencari kosakata yang tertera di dalam teka-teki silang tersebut.

Apalagi jiga guru mampu mendesain media ini sedemikian rupa akan lebih membuat suasana belajar semakin menarik. Siswa terlibat secara emosional dan bebasa berkreasi di bawah koor-dinasi guru kelas. Penerapan me-dia teka teki silang bukan saja da-pat mempermudah dan mengefek-tifkan proses pembelajaran, akan tetapi juga diharapkan bisa mem-buat proses pembelajaran lebih menarik, dan siswa pun terhindar dari kejenuhan dan bosan dalam proses pembelajaran. Sebuah terobosan baru menerapkan teka teki silang untuk meningkatkan keterampilan berbahasa siswa.

Selanjutnya, rekomendasi diberi-kan kepada guru, agar dapat menggunakan berbagai variasi penggunaan media salah satu media teka-teki silang di dalam pembelajaran, sehingga mampu menciptakan ruang kelas yang menyenangkan bagi siswa, dan bagi pihak sekolah, agar mem-berikan dorongan kepada setiap guru agar mau berkreativitas dalam melaksanakan pembelajaran sehingga akan mendapatkan hasil belajar yang lebih baik.

\section{REFERENSI}

Arsyad, A. (2009). Media Pembelajaran . Jakarta: RajaGrafindo.

Anurag Saxena, MD, Raenelle Nesbitt, Punam Pahwa, Sheryl Mills. (2009). 
"Crossword Puzzles Active Learning in Undergraduate Pathology and Medical Education". Arch Pathol Lab Med_-Vol 133, September 2009.

Aribowo, AEric Kunto. (2014). "Media Pembelajaran DIY Membuat Flash Card Dan Teka-Teki Silang Mandiri”. Makalah ilmiah.

Aqib, Zainal. (2014). Model-model, Media, dan Strategi Pembelajaran Kontekstual (Inovatif). Bandung: Yrama Widya

Ermaita, Pargito, dan Pujiati . (2016) Penggunaan Media Pembelajaran Croissword Puzzle untuk Meningkatkan Keterampilan Berpikir Kreatif Siswa. Journal Article Jurnal studi sosial 2016 fkip.unila.ac.id

Iglika, Pavlova, V.; Lewis, Kayla C. (2013). "An Easy \& Fun Way to Teach about How Science "Works": Popularizing Haack's Crossword-Puzzle Analogy". American Biology Teacher, v75 n6 p397-401 Aug 2013

Khalilullah, M. (2012). "Permainan TekaTeki silang sebagai Media dalam Pembelajaran Bahasa Arab (Mufdrat). An-nida Jurnal Pemikiran Islam”. Vol 37, No. 1.2012.

Laksmi, K., I Wayan Sujana, dan I.B. Gd. Suryaabadi. (2014). "Pengaruh Model pembelajaran Berbasis Otak (Brain Based Learning) Berbantuan Media Teka-Teki Silang terhadap Hasil Belajar IPS Siswa Kelas V SD Gugus I Gusti Ngurah Jelantik". Dalam Jurnal Mimbar PGSD Universitas Pendidikan anesha. Volume 2 Nomor 1, Tahun 2014.

Merkel, Warren (2016). "The Potential of Crossword Puzzles in Aiding English Language Learners". TESOL Journal, v7 n4 p898-920 Dec 2016, The Journal of Effective Teaching an online journal devoted to teaching excellence.

Mirzandani. (2012). "Meningkatkan Kemampuan Membaca Kata melalui Media Teka-Teki Silang Bergambar bagi Anak Tunagrahita Ringan: Penelitian Tindakan Kelas di DV/C SLB Bina Nagari Solok Selatan”. Dalam Jurnal Ilmiah Pendidikan Khusus. Volume 1 Nomor 2, Mei 2012. Hlm. 306-317.

Priantini, Friska Novita, Prana Dwija Iswara, dan Isrok'atun. (2016). "Penggunaan Media Tega (Teka-Teki Gambar Dan Audio) Untuk Meningkatkan Keterampilan Menyimak dalam Materi Menjelaskan Simbol Daerah/Korp". Jurnal Pena Ilmiah: Vol. 1, No. 1 (2016)

Pooja; Singh, Sushil Kumar. (2015). "Effectiveness of Selected Teaching Strategies in Relation to the Learning Styles of Secondary School Students in India". Interchange: A Quarterly Review of Education, v46 n3 p289-312 Aug 2015

Rahmah, Linda Agustina. (2015). "Penerapan Media Pembelajaran Crossword Puzzle untuk Meningkatkan Hasil Belajar Ekonomi pada Kompetensi Dasar Konsep dan Pengelolaan Koperasi Kelas X IIS 2 di 
SMA Negeri 1 driyorejo Gresik. Jurnal Pendidikan ekonomi (JUPE). Vol. 4 No. 32016.

Rantika dan Faisal Abdulah (2015). "Penggunaan Media Teka Teki Silang dalam Meningkatkan Hasil Belajar siswa Kelas II pada Pembelajaran Bahasa Arab di Madrasah Ibtidaiyahnurul Iman Pengabuan Kabupaten Pali. Volume 1. Januari 2015

Retno et al.,(2015). "Penggunaan media Crossword Puzzle untuk Meningkatkan Aktivitas dan Hasil Belajar Siswa Kelas IV B SD Negeri Jember Lor 02 pada Mata Pelajaran IPA Pokok Bahasan Perubahan Penampakan pada Bumi dan Benda Langit Tahun Ajaran 2014/2015.

Sushama, Joag, D. (2014). “ An Effective Method of Introducing the Periodic Table as a Crossword Puzzle at the High School Level". Journal of Chemical Education, v91 n6 p864-867 Jun 2014

Tarigas, Theodora Dara. (2014). "Pengembangan Media Crossword Puzzle Chemistry (Cropchem) pada Materi Struktur Atom di SMA".

Tricia M. Davis, Brooke Shepherd, Tara Zwiefelhofer. (2009). "Do Crossword Puzzles Help in the Success of Student Learning?" University of Wisconsin, River Falls, WI 54022

Warren, Merkel, (2016). "The Potential of Crossword Puzzles in Aiding English Language Learners" TESOL Journal, v7 n4 p898-920 Dec 2016

Wiwat, Orawiwatnakul. (2013). "Crossword Puzzles as a Learning Tool for Vocabulary Development". Electronic Journal of Research in Educational Psychology, v11 n2 p413-428 Sep 2013

Crossword Puzzles as a Learning Tool for Vocabulary Development September, 2013, DOI: $10.14204 /$ ejrep.30.12186

\section{Article Metadata:}

Syofiani. Zaim, M. Syahrul R. Agustina. (2018). Improving Student' Language Skills through Ustilizing Cross Word Puzzle: Creating Fun Classes, Ta'dib, 21 (2), 87-98. http://dx.doi.org/10.31958/jt.v21i2.1232

Keywords: Cross Word Puzzle, Language skills, Fun classes

Coresponding author: Syofiani, Universitas Bung Hatta, syofiani.jufri@ gmail.com 